\title{
Relationship between Self-Esteem and Achievement Motivation among Undergraduates in South Eastern Nigeria
}

\author{
${ }^{1}$ Dr. Barnabas E. Nwankwo, ${ }^{2}$ Tobias C. Obi and ${ }^{3}$ Solomon A. Agu \\ Department of Psychology, Caritas University Enugu \\ Department of Psychology, Enugu State University of Science and Technology, Enugu
}

\begin{abstract}
This study examined the relationship between self esteem and achievement motivation among university undergraduates. The sample consists of 100 male and 100 female undergraduates from the University of Nigeria, Enugu campus (UNEC) with the age range of 18-35. Correlational design was used. Hudson (1982) 25-item index of self-esteem scale and Hermann (1970) 29-item achievement motivation scale were administered. Pearson product moment correlation coefficient statistics revealed a positive relationship between self esteem and achievement motivation, $r(198)=0.34$ at $p<.05$. The findings were discussed and suggestions made.
\end{abstract}

\section{Introduction}

There has been a growing decline in academic performance among young people in Nigeria. The recent past West African Examinations (WAEC) and The National Examinations (NECO) have recorded a bysmal poor results across the federation. There is a show of non challancy among the youths in academic excellence. The motivation to achieve and excel is on the low level. Can this low achievement motivation be attributed to personality differences? A lot has been attributed to an individual's personality. There is a consistent pattern of behaviour across many situations in which an individual can be compared and differentiated from another. Since our behaviors also reflect the view we have of ourselves and the way we value the various parts of our personalities; thus the component of personality that encompasses our positive and negative self evaluations is what is called self-esteem. Self esteem is a psychological term that reflects a person's overall evaluation or appraisal of his or her own worth. It encompasses beliefs (for example "I am competent" "I am worthy") and emotions such as triumph, despair, pride and shame (i.e. self concept) one hold about him/herself. Although people have a general level of self-esteem, it is not uni-dimensional. We may see ourselves positively in one domain but negative in another. For example, a good student may have a general high level of self esteem in academic domain but lower self-esteem in sports (Morretti and Higgins 1990; Baumeister, 1998; Crocker and Parker 2004). Self esteem has strong cultural components such as high relationship harmony (i.e. a sense of success in forming close bonds with other people) especially in collectivist cultures like Asia than it is, in more individualistic western societies (Kwan, Bond and Singelis 1997; Spencer Rogers et al, 2004). Although everyone goes through periods of low self-esteem (after for instance, an undeniable failure), some people are chronically low in self-esteem. For them failure seems to be an inevitable part of life such that it may lead to a cycle of failure in which past failure breeds future failure. Simply put, self-esteem is the positive or negative evaluation of the self. As can be deduced from the above it is crystal clear that the kind of attitude one hold about himself can either make or mar the individual and it is a personal judgment of worthiness that is expressed in the attitudes the individual holds about himself. Furthermore, it is worth noting that there are two subtypes of self-esteem which are implicit self-esteem and explicit self-esteem. Implicit self-esteem refers to a person's disposition to evaluate him/herself positively or negatively in a spontaneous automatic or unconscious manner. Explicit self-esteem entails more conscious and reflective self evaluations.

\section{Self Esteem}

The concept of self esteem can be explained using the theory of sociometer. It is a theory of self-esteem from an evolutionary psychological perspective that proposes that state self-esteem is a gauge for (or sociometer) of interpersonal relationships. It is a theoretical perspective that was first introduced by Leary and colleagues in 1995. Their major position is that self-esteem is the relationship between one's real self and one's ideal self, feeding off of favorable behaviors (Leary et al , 1995; Leary \& Banmeister 2000). Sociometer as proposed by Leary and his colleagues is a measure of how desirable one would be to other people and this is influenced by self-esteem and this measure may be made in a variety of terms such as team member, relation pattern, employee, colleague, or numerous other ways. This theory however is useful in explaining why people are so concerned with self-esteem and this measure helps to guide people through their social interactions on a daily basis. In a glance, Leary proposed that self-esteem is a gauge that monitors interaction between people and 
send signals to the person to keep them in check with how socially acceptable their behavior are. Thus, this theory is also based off of the notion that all human have an inherent desire to have interpersonal relationship, to maintain these in a productive manner and that people have evolved to have a psychological gauge for sensing signals from these interactions concerning how well their behavior are integrating them into the society as well as how much they are being accepted or rejected (Yamaguchi et al. 2007, Leary \& Banmeister, 2000). However, according to Leary \& Banmeister, 2000) there are two common distinctions made in self-esteem and they are

1. State self-esteem

2. Trait self-esteem

State self-esteem refers to the fluctuation in people's feelings about themselves as a result of how they perceive others and currently value their relationship. That is, self-esteem is raised or lowered based on positive or negative feedback. Trait self-esteem on the other hand refers to the sense and belief a person who is generally valued and accepted by others has. This is also sometimes referred to as the resting state for the sociometer because this is how the person feels when relational information is absent (Leary \& Banmeister 2000).

\section{Achievement Motivation}

This is the motivation to achieve. Rightly put, it is a stable learned characteristic in which a person obtains satisfaction by striving for and attaining a level of excellence. It also refers to an individual's desire for significant accomplishment, mastering of skills control or high standards (McClelland et al, 1953). It has been found that people with a high need for achievement seek out situations in which they can compete against some standard, that is, be it grades, money or winning at a game and proving themselves successful. Such individuals, in picking their challenges, tend to avoid situations in which success will come too easily (i.e. which would be unchallenging) and situations in which success is unlikely to come. However, people low in achievement motivation tend to be motivated primarily by a desire to avoid failure as a result they seek out easy task being sure to avoid failure or seek not very difficult task for which failure has no negative implications. Such people with a high fear of failure will stay away from task of intermediate difficulty because they may fail where others have been successful (Atkinson and Feather 1966). Achievement motivation is assciated with the following range of actions. These include "intense, prolonged and repeated efforts to accomplish something difficult, to work with singleness of purpose towards a high and distant goal, to have the determination to win". And also, the concept of achievement motivation or the need for achievement was popularized by the psychologist David McClelland. The need for achievement theory by McClelland (1961), refers to an individual preference for success under conditions of competition and the need for achievements has been studied both at the individual and societal level. However, the main objective behind this theory is to understand characteristics of higher need achievers, the outcome associated with high need achievement and method of increasing the need for achievement. The theory posits that people with a high need for achievement tend to set moderately difficult goals, make moderately risky decisions, want immediate feedback, become preoccupied with their task and assume personal responsibility (Moorhead and Griffin, 1995). Furthermore, McClelland posits that proper training could greatly boost an individual's need for achievement and that a nation's level of achievement of economic prosperity correlates with its citizens need for achievement. Finally, just like every manifest need theory, need for achievement posits that these needs are not solely instinctive, rather they can be learned by people as they go about their day to day lives. It has been found that people with high self-esteem have performance expectations higher than those of low self-esteem (Atkinson, Bastian, Earl and Litwin, 1960; Covington and Omelich, 1979). No wonder, some undergraduates in university do better than others when faced with the same task, the probability of success estimate of high self-esteem people will therefore be higher than those of low self-esteem people. Although the two factors which are self-esteem and achievement motivation are completely independent, the warping of probability of success of self-esteem correlates with achievement motivations. Thus, high self-esteem becomes a factor leading to good performance that justifies the initial achievement motivation. In addition self-esteem is also supported by a number of articles showing that selfesteem correlates positively with educational and occupational accomplishment (Coopersmith, 1967). The purpose of the study is to find out if there is a significant positive relationship between self-esteem and achievement motivation among university undergraduates.

\section{Hypothesis}

The hypothesis stated below was tested:

There will be a significant positive relationship between self-esteem and achievement motivation among university undergraduates.

\section{Design/statistics}

\section{Method}


Correlation design was adopted based on the relationship between self-esteem and achievement motivation. Then Pearson product moment correlation coefficient was applied as statistical test for data analysis.

\section{Participants}

This study made use of 200 participants comprising of 100 male and 100 female undergraduates from the University of Nigeria Enugu Campus (UNEC) south eastern Nigeria. The participants were seen at the cafeteria and randomly selected. It was during lunch time and fortunately a large number of undergraduates from the university from all faculties were available at the cafeteria and so represent the entire population of undergraduates of in University.

\section{Measures}

\section{Index of Self-esteem (ISE)}

A 25-item questionnaire developed by Hudson (1982) to measure the level of self-esteem was adopted for the study. It was designed to measure the self perceived and self-evaluative component of self-concept which is the sum total of the self-perceived and the other perceived views of the self held by the person. Hudson (1982) obtained a reliability coefficient of 0.92 , but was validated here in Nigeria by Onighaiye (1996), who obtained a reliability coefficient of 0.46 using Nigeria samples.

Hermann Achievement Motivation Scale (HAM)

A 29-item Eyo(1986) adaptation of the Hermann measure of achievement motivation scale was used to measure participant's level of achievement motivation. Hermann (1970) obtained a reliability coefficient of 0.70 but was adopted for study here in Nigeria by Eyo(1986) who obtained a reliability coefficient of 0.56 using Nigerian samples. Direct score items: - 1,2,8,9,10,11,12,13,16,17,19,20,24. Reverse score items: $3,4,5,6,7,14,15,18,21,22,23,25$. Add together the result of the direct score and reverse score items to obtain the overall score. The Nigerian norms or mean scores are the basis for interpreting the scores of charts. Scores higher than the norms 30 indicates that the clients have low self-esteem. The lower a score is below the norms, the higher the clients self esteem. ISE measures how poor a client's self-esteem is.

\section{Procedure}

A total of 220 copies of Index of self-esteem and Hermann's questionnaire for achievement motivation (HAM) were randomly distributed to 220 participants which was initially selected for the study based on the correlative nature of the research and inappropriate filling by 20 participants, 100 male and 100 female were used for the research. The observed scores on the two variable were tabulated after scoring to identify whether a relationship exist.

\section{Results}

Table 1. Summary table of Pearson product moment correlation coefficient on the relationship between self-esteem and achievement motivation among university undergraduates.

Hypothesis:

The hypothesis stated below was tested:

There will be a significant positive relationship between self-esteem and achievement motivation among university undergraduates.

\begin{tabular}{|l|l|l|l|l|l|l|l|l|}
\hline $\mathrm{N}$ & $\sum \mathrm{x}$ & $\sum \mathrm{y}$ & $\sum \mathrm{x}^{2}$ & $\sum \mathrm{y}^{2}$ & $\sum \mathrm{xy}$ & $\mathrm{r}$ & $\mathrm{df}$ & $\mathrm{P}$ \\
\hline 200 & 9631 & 11358 & 513277 & 676062 & 558839 & 0.34 & 198 & $<.05$ \\
\hline
\end{tabular}

From table 1 above, r-calculated value of 0.34 is found to be greater than $r$-critical value of 0.25 at $p<.05$ level significance. Therefore, the hypothesis which states that "there will be a significant relationship between selfesteem and achievement motivation among university undergraduates", is confirmed. A significant positive relationship was observed to exist between self-esteem and achievement motivation among university undergraduates.

\section{Discussion}

The aim of this study was to examine the relationships between self-esteem and achievement motivation among university undergraduates and based on the outcome of this study, one can comfortably say that there exist a positive correlation between self-esteem and achievement motivation among undergraduates.

This implies that when self esteem increases, the level of achievement motivation increases too. One can say the reasons why most university undergraduates achieve lowly especially in their academics is as a result of low self esteem which is how they percieve or evaluate themselves. Thus this finding or research supports the positions of Korman (1970) and Kulka (1972) which say that the factor that differentiates people with high achievement motivation from low achievement motivations is self-esteem and that high achievers 
have higher self-esteem than low achievers. The implication of this study is that self-esteem has a significant relationship with achievement motivation among university undergraduates and can be predicted that those with high self-esteem will also have high achievement motivation and achieve more than those with low self-esteem. Also, self esteem can be improved on to also improve achievement motivation among university undergraduates. We've long known that when students feel good about themselves, they are much more likely to become better achievers in the classroom. Building students' confidence by setting them up for success and providing positive feedback along with frequent praise are essential tools for both teachers and parents in building the self esteem of their children. Think about yourself, the more confident you feel, the better you feel about the task at hand and your ability to do it. When children feel good about themselves, it's much easier to motivate them to become academically proficient. What's the next step? First of all, in order to help improve self-esteem, we have to be careful in the way we provide feedback. Dweck (1999) argues that having a particular goal orientation, (learning goal or performance goal) to base feedback on as opposed to personorientated praise will be more effective. In other words, avoid using statements like: 'I'm proud of you'; Wow, you worked hard. Instead, focus the praise on the task or process. Praise the student's specific effort and strategy. For instance, 'I notice you selected the cube-a-links to solve that problem, that's a great strategy.' I noticed that you didn't make any computational errors this time!' (Dweck, 1999). When using this type of feedback, you've addressed both self-esteem and you've supported the child's motivational level for academic goals. Self-esteem is important in and out of the classroom. Teachers and parents can support self-esteem by remembering some of the following: Always accentuate the positive. Do you ever notice those suffering from a low self- esteem tend to focus on the negative? You'll hear statements like: 'Oh, I was never any good at that. 'I can't keep friends'. This actually indicates that this person needs to like themselves more. Prompt them to state things they can do well, things they feel good about. You will be surprised at how many children suffering with low self-esteem have difficulty with this task - you'll need to provide prompts. Avoid criticism. Those suffering with low self-esteem struggle the most when given criticism. Be sensitive to this. Always remember that selfesteem is about how much children feel valued, appreciated, accepted, loved and having a good sense of self worth. Understand that as parents and teachers, you play one of the biggest roles in how good or bad a child can feel about themselves. Also avoid criticism. Influence from a parent or teacher can make or break a child's sense of self-esteem. Don't abuse it. Expectations must always be realistic. This goes along with setting children up for success.

\section{Conclusion}

From the findings of this study, the researchers hereby conclude that "self-esteem is positively related to achievement motivation" among university undergraduates. Self-esteem is an important component to almost everything people do especially young ones. Not only will it help with academic performance, it supports social skills and makes it easier for children to have and keep friends. Relationships with peers and teachers are usually more positive with a healthy dose of self-esteem. Children are also better equipped to cope with mistakes, disappointment and failure, they are more likely to stick with challenging tasks and complete learning activities. Self-esteem is needed life-long and we need to remember the important roles we play to enhance or damage a child's self-esteem.

\section{References}

[1]. Atkinson, J. \& Feather, N. (1966). A theory of achievement motivation. New York: Wiley and Sons.

[2]. Atkinson, J.W., Bastian, J.R., Earl, R.W., \& Litwin, G.H. (1960). The achievement motive, goal-setting, and probability preferences. Journal of Abnormal Social Psychology, 66, 27-36.

[3]. Baumeister, R.F. (Ed.) (1999). The Self in Social Psychology. Philadelphia, PA: Psychology Press (Taylor \& Francis).

[4]. Coopersmith, S. (1967). The antecedents of Self-esteem. New York: W.H. Freeman Covington, M. V. \& Omelich, C. L. (1979). Effort: The double-edged sword in school achievement. Journal of Educational Psychology, 71(2), 169-182.

[5]. Crocker .J. and Parker, L.E. (2004). "The costly pursuit of self-esteem" Psychological Bulletin 130 (3), $392-414$.

[6]. Dweck, C. S. (1999). Self Theories: Their Role in Motivation, Personality, and Development. Hove: Psychology Press, Taylor and Francis Group

[7]. Eyo, I. E. (1986). Nigerian adaptation of Herman's Questionnaire Measure of Achievement Motivation. Nigerian Journal of Psychology. 5, 52-71.

[8]. Hudson, M. (1982). Test Construction. Psychological Corporation, Chicago.

[9]. Kulka, A. (1972). Attribution determinants achievement related to behavior. Journal of Personality and Social Psychology. 72 (21) $166-174$.

[10]. Leary, M.R., \& Baumeister, R.F. (2000). The nature and function of self-esteem: Sociometer theory. In M. Zanna (Ed.), Advances in experimental social psychology (Vol. 32, pp. 1-62). San Diego, CA: Academic Press.

[11]. Leary, M.R and Dwk, D.L (1995). Interpersonal functions of the self-esteem system as a sociometer. In M.H Kernis (Ed) efficacy, agency and self-esteem (pp 123-144). New York: Plenum press.

[12]. Leary, M.R. and Baumeister, R.F (2000). The Nature and functions of self-esteem. Sociometer theory. In M.P Zanna (Ed) advances in experimental Social.

[13]. Leary, M.R. (1999) Making Sense of Self-Esteem. Current Directions in Psychological Science 8 (1), 32-35. 
[14]. Kirkpatrick, L. A., \& Ellis, B. J. (2001). An evolutionary-psychological approach to self-esteem: multiple domains and multiple functions. In G. J. O. Fletcher \& M. S. Clark (Eds.), Blackwell handbook of social psychology: Interpersonal processes (pp. 411 436). Oxford, UK: Blackwell Publishers.

[15]. Korman, A. K. 1970. Toward an hypothesis of work behavior. Journal of Applied Psychology, 54: 31-41.

[16]. Kwan, V. S. Y., Bond, M. H., \& Singelis, T. M. (1997). Pancultural explanations for life-satisfaction: Adding relationship harmony to self-esteem. Journal of Personality and Social Psychology, 73, 1038-1051.

[17]. McClelland, D.C. (1965). Achievement motivation can be developed. Harvard Business Review ,43 (November, December ) 68 .

[18]. McClelland, D.C. (1961). Method of measuring Human motivation. In John W Atkison (Ed) the achieving society (Princeton N.) D Van Nostrand, pp 41-43.

[19]. Moorhead, G. \& Griffin, R.W.(1995). Organization Behaviour. Managing peopleand organization. Houghton Mifflin Company. Boston.

[20]. Moretti, M. M., \& Higgins, E. T. (1990). The development of self-system vulnerabilities: Social and cognitive factors in developmental psychopathology. In R. J. Sternberg \& J. Kolligian (Eds.), Competence considered (pp. 286-314). New Haven, CT: Yale University Press.

[21]. Onighaiye, M. A (1996). The impact of length of time in the university on ego-identity, self-esteem and stress manifestation in students. Unpublished B. sc Thesis, Psychology Department, University of Lagos

[22]. Sternberg \& J. Kolligian (Eds.), Competence considered (pp. 286-314). New Haven, CT: Yale University Press.

[23]. Spencer-Rodgers, J., Boucher, H.C., Mori, S.C., Wang, L., \& Peng, K. (2009). The Dialectical Self-Concept: Contradiction, Change, and Holism in East Asian Cultures. Pers Soc Psychol Bull; 35; 29.

[24]. Yamaguchi, S., Greenwald, A. G., Banaji, M. R., Murakami, F., Chen, D., Shiomura, K., Kobayashi, C., Cai, H., \& Krendl, A. (2007). Apparent universality of positive implicit self-esteem. Psychological Science, 18, 498-500. 